\title{
Audit on Factors Causing Cost Over Runs in Construction Industry
}

\author{
S. Venkatraman, Anish.C, S.Rajesh, R.Venkatakrishnaiah
}

\begin{abstract}
Development has become a significant player in the economy of numerous nations, particularly created nations. Development can be considered as a unique industry which is always confronting vulnerabilities. These vulnerabilities and the numerous partners in these sorts of ventures, make the administration of costs troublesome which thus causes cost invades. Thusly, cost overwhelms are viewed as one of the most basic issues during the execution of development ventures. What's more, in this undertaking we likewise discover how to look with venture cost topples and limit of cost over runs in point by point investigation of this task. Undertaking in which the cost invade of the venture surpasses 10 percent of the underlying spending plan.
\end{abstract}

Key Words: Undertaking, troublesome, development ventures

\section{INTRODUCTION}

This project is to minimize the cost overrun by using various lean technologies in order to achieve cost savings, space savings etc. And evaluate the factors that have a contribution to cost overruns in construction projects. The scope of the study is focused to reduce or minimize cost overruns in construction site through implementation of lean tools. To identify an effective lean tool for minimizing the cost overrun through existing literatures. Obtaining the cost overruns in percentage with the help of lean tool and comparing with existing journal results.[1]-[6]

The general methodology of study involves collection of data about lean tools and how to implement in various construction sites. Collection of major construction activities also involved in this research methodology. A thorough literature review was initially conducted to identify the various lean technology involved to minimize the waste in construction site.

The data has been collected by interviewing the officials of the construction industry. The study has been broadly undertaken as follows:

Revised Manuscript Received on December 11, 2019

S. Venkatraman, Department of Civil Engineering, Bharath Institute of Higher Education and Research, Chennai, India. Email: mailmagik@yahoo.com

Anish.C, Department of Civil Engineering, Bharath Institute of Higher Education and Research, Chennai , India. Email: anishdavidpaul@gmail.com

S.Rajesh, Department of Civil Engineering, Bharath Institute of Higher Education and Research, Chennai , India. Email: rajeshskr06@gmail.com

R.Venkatakrishnaiah, Department of Civil Engineering, Bharath Institute of Higher Education and Research, Chennai, India. Email: venkatapec@gmail.com

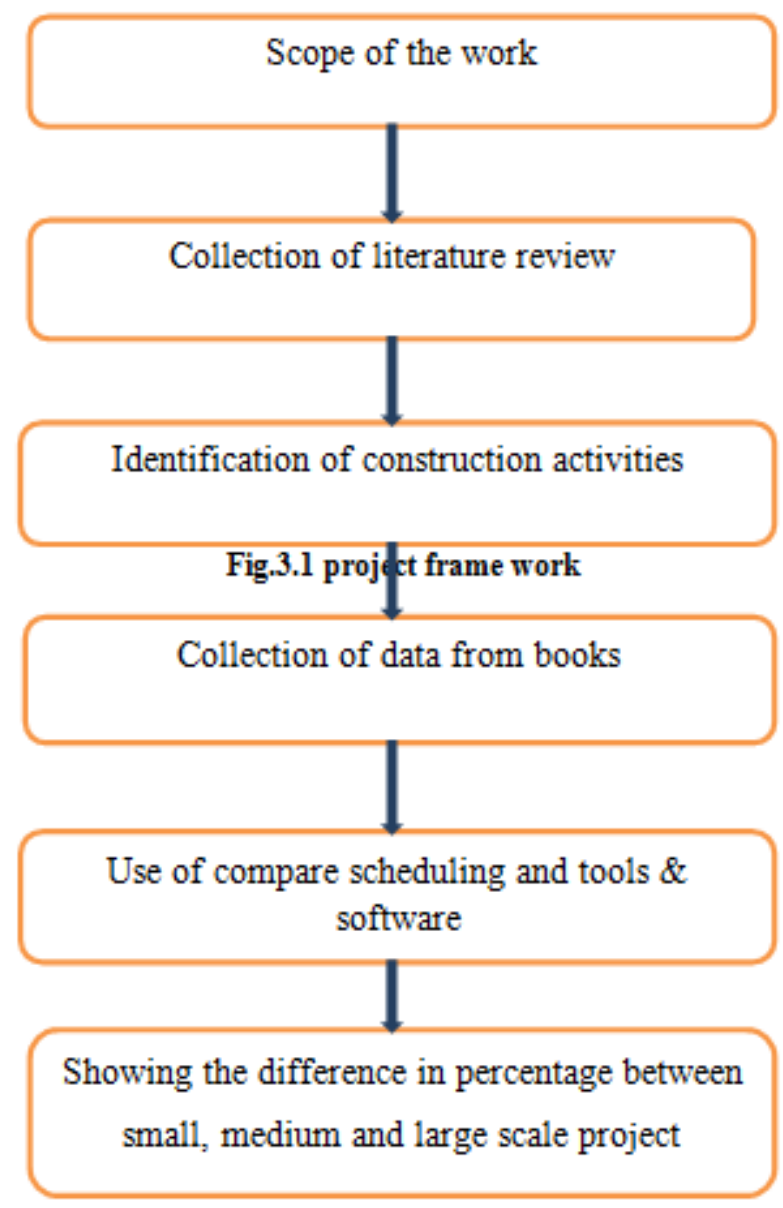

Fig.1 project frame work

\section{ELEMENT OF COST OVER RUNS}

It should be noted that the questionnaire has been designed so that the interviewee is able to highlight the major factor which causes the over-cost, with a coefficient higher than other factors. The elements likely to cause cost overruns are: - Architecture of structures;

- Building technology;

- Quality of the building materials;

- Construction cost estimate;

- Scheduling and organization of construction projects;

- Quality of the labor; [7]-[12]

- Conflicts between the various stakeholders in the construction,

- Supply of building materials,

- Weather,

- Industrial accidents.

We set out some hypotheses in order to quantify the responses extracted from the survey. So: 
- Each factor is likely to generate an over-cost and represents an initial proportion of at least $1 \%$;

- The interviewee expresses the proportion of the cost factor within a range from $1 \%$ to $90 \%$ depending on the magnitude of the contribution of the factor in the failure of the construction project.

- The sum of the percentages must equal $100 \%$ for each construction task. The average weight of a factor for each task is calculated from the following expression:

$(\mathrm{x})=\frac{\sum_{i=1}^{p} \text { nisi }}{n}$

With:

$\langle\mathrm{x}\rangle$ : The weighted average of the proportion of a factor;

$\mathrm{n}$ : Size of the sample;

p: Factor of over-cost;

xi: Proportion allocated to a factor by respondents;

ni: Frequency corresponding to .

\section{RESULTS}

The architecture of structures, scheduling and the organization of construction sites, the quality of the labor and conflicts between different stakeholders in the construction do not appear to cause significant cost overruns because their respective weight is less than $5 \%$.

Technical problems, in particular the architecture of the structures and building technology, could be quite easily resolved. Why we should entrust the job to qualified persons in order to avoid the presence of defects in building materials such as concrete, aggregates, steel, etc., normally should be tested prior to use. However site laboratories, where could be conducting the tests are rarely found, hence the risk of dubious quality materials be used in the construction of a building. These shortcomings have harmful consequences for the solidity of the structure. When it looks dangerous, the resumption of the works becomes inevitable, which invariably results in significant over costs. The construction cost estimation methods are not quite fine. It often leads to a relatively coarse initial estimated budget, illustrating by an almost lack of precision and with no margin for reliable tolerance. This could explain in large part the fact that the initial budgets often show very important deviations compared to the final construction project cost.

The problems of management appear to be more complex for their resolution. For example regarding the organization of tasks, the methods used by a large number of contractors and companies indicate that they merely content with empirical practices rather than scientific methods of scheduling and the critical path such as PERT (Program Evaluation and Review Technique) or the CPM (Critical Path Method). These bad practices usually lead to trial and error and to arbitrary decision-making by the site foreman, causing delays which, in turn, generate constructions cost overruns [Louzolo, 2005].

This phenomenon of non-compliance of the deadline, very common in sites, so not only increases the cost of labor, but also of rental equipment used. Searching for the design and implementation of construction projects. The

cheap labor often leads contractors to recruit low-skilled workers. Unfortunately, it happens in this case that structures are poorly executed, with major effect to the resumption of works. Task duration is then extended, resulting at the end by time overruns and therefore cost overruns. Conflicts between certain stakeholders in construction, i.e. the owner, the contractor, technical controller, the technician and utilities, are also caused delays in the start of projects, preparation and organization of construction sites, and the performance of the works. The supply of building materials is often carried out continuously and in small quantities throughout the implementation phase, because the space for the storage of materials is reduced. A consequence to this bad procedure is that stock-outs occur fairly regularly as long as an unexpected disruption arises. [13]-[20]

Moreover imported materials are experiencing price fluctuations, in addition to random and long delivery times. All this often causes the work stoppage, even extending the original deadline for project completion, with its corollary which is the construction cost overruns. Weather sometimes causes damage during implementation of certain structures if prior precautions are not observed. This is particularly the case for the distribution slab requiring protection against rain, because its implementation must be done without stopping, otherwise it could be forced to resume carrying out of the works. In any case, weather conditions, as shown by two remarkable studies led respectively by Moselhi and El-Rayes, may have an adverse impact on the duration and cost of the construction activities [Moselhi et al., 1997; El-Rayes et al., 2001]. Labor accidents result in injuries that are sometimes serious. These accidents are often the consequence of nonobservance of the safety rules. When they occur, disruptions are occurring in the course of the works, and then causing delays that promote the construction cost overruns.

Note that in the survey that we conducted, expert advisors make no explicit reference to the interest of time, proof that this crucial aspect seems relegated to the background. In fact, through the elements of cost overruns mentioned, particularly scheduling, conflict between different stakeholders, the supply of materials, weather and labor accidents, the most harmful consequences they generate are show up on time, causing significant delays in carrying out deadline. [21]-[26]

Knowing that the costs and durations are inextricably linked, any delay could then result in substantial construction cost overruns [Hutcheson, 1990; Ogunlana et al., 1996; AlMomami, 2000; Akpan et al., 2001; Aibinu et al., 2002; Frimpong et al., 2003-a-b; Louzolo, 2005; 2007; 2014].

So, fight against time overruns is implicitly troubleshoot conflicts, the supply of materials, scheduling, meteorology, etc.

\section{Causes of delay:}

Consultant related factors

Contractor related factors

Poor site management and supervision, Design related factors Equipment related 
factors, External related factors;

Theft done on site, Materials related factors

\section{Voiding Cost Overruns In Construction Projects In} India

\begin{tabular}{|l|l|}
\hline CASUSE & REASON FOR GIVEN INTERVIEW \\
\hline $\begin{array}{l}\text { Incompetency of the project manager Lack of } \\
\text { experience and skills in the manager } \\
\text { Poor relation between the client and contractor } \\
\text { Clients had constant complaints regarding the } \\
\text { quality of the job } \\
\text { Client was unwilling to help No proper } \\
\text { relationship with contractor } \\
\begin{array}{l}\text { Client had constant changes of design Client had } \\
\text { lacked properunderstanding regarding the project } \\
\text { Incompetency of the project manager }\end{array}\end{array}$ \\
\hline Poor relation between the client and contractor & \\
\hline Client was unwilling to help & $\begin{array}{l}\text { Clients had constant complaints regarding the } \\
\text { quality of the job }\end{array}$ \\
\hline Client had constant changes of design & No proper relationship with contractor \\
\hline & $\begin{array}{l}\text { Client had lacked proper understanding regarding } \\
\text { the project }\end{array}$ \\
\hline &
\end{tabular}

\section{CONCLUSION}

After understanding the importance of reducing cost over runs in construction process the project topic has been identified as minimizing cost over runs in the construction project through the implementation of lean construction. A brief review of literature had been presented. After going through all the literature reviews it was noticed that the minimum results are available in lean technology in construction. [27]-[34]

Time and cost invade have been a significant repeating issue in development industry. Brief purposes behind time overwhelms as announced by different venture actualizing offices are delay in land securing, delay in hardware erection, lacking activation by the temporary worker, delay in timberland freedom, subsidize imperatives, change in extent of work, wiping out of delicate, law and request issue, delay in supply of gear, slow progress of common work, acceleration in cost. Understanding the significance of subject, development postpone brings about time invade as well as in cost overwhelm. There are different causes because of which venture experiences these delays.Contractor's ill-advised arranging and booking have more effect on venture length, just as absence of experience will influence the capacity of basic leadership which will result in revise and financing issues. Specialist's ill-advised drawings, late reconsidering the determination, less coordination with temporary worker additionally finish up in venture time overwhelm.

\section{REFERENCES}

1. Iyappan L., Dayakar P., Identification of landslide prone zone for coonoortalukusing spatial technology, International Journal of Applied Engineering Research,V-9,I-22,PP-5724-5732,Y-2014.

2. Kumar J., Sathish Kumar K., Dayakar P.,Effect of microsilica on high strength concrete, International Journal of Applied Engineering Research,V-9,I-22,PP-5427-5432,Y-2014.

3. Dayakar P., Vijay Ruthrapathi G., Prakesh J., Management of bio-medical waste, International Journal of Applied Engineering Research,V-9,I-22,PP-5518-5526,Y-2014.

4. Swaminathan N., Dayakar P., Resource optimization in construction project, International Journal of Applied Engineering Research,V-9,I-22,PP-5546-5551,Y-2014.

5. Venkat Raman K., Dayakar P., Raju K.V.B.,An experimental study on effect of cone diameters in penetration test on sandy soil, International Journal of Civil Engineering and Technology,V-8,I-8,PP-1581-1588,Y-2017.

6. Saritha B., Chockalingam M.P.,Photodradation of malachite green DYE using TIO2/activated carbon composite,International Journal of Civil Engineering and Technology,V-8,I-8,PP-156-163,Y-2017

7. Shendge R.B., Chockalingam M.P., Saritha B., Ambica A.,Swat modelling for sediment yield: A case study of Ujjani reservoir in
Maharashtra, India,International Journal of Civil Engineering and Technology,V-9,I-1,PP-245-252,Y-2018

8. Chockalingam M.P., Balamurgan V.,Modernisation of an existing urban road-sector in Chennai, a case study report,International Journal of Civil Engineering and Technology,V-8,I-8,PP-1457-1467,Y-2017

9. Saritha B., Chockalingam M.P.,Adsorption study on removal of basic dye by modified coconut shell adsorbent, International Journal of Civil Engineering and Technology,V-8,I-8,PP-1370-1374,Y-2017

10. Saritha B., Chockalingam M.P.,Adsorptive removal of heavy metal chromium from aqueous medium using modified natural adsorbent,International Journal of Civil Engineering and Technology,V-8,I-8,PP-1382-1387,Y-2017

11. Chockalingam M.P., Palanivelraja S.,Retrospective analysis of a theoretical model used for forecasting future air quality near the north Chennai thermal power plant,International Journal of Civil Engineering and Technology,V-8,I-8,PP-1457-1467,Y-2017

12. Saritha B., Chockalingam M.P.,Photodegradation of methylene blue dye in aqueous medium by Fe-AC/TiO2 Composite,Nature Environment and Pollution Technology,V-17,I-4,PP-1259-1265,Y-2018

13. Shendge R.B., Chockalingam M.P., Kaviya B., Ambica A.,Estimates of potential evapotranspiration rates by three methods in upper Bhima Basin, In Maharashtra, India,International Journal of Civil Engineering and Technology,V-9,I-2,PP-475-480,Y-2018

14. Shendge R.B., Chockalingam M.P.,The soil and water assessment tool for Ujjani Reservoir,International Journal of Mechanical Engineering and Technology,V-9,I-2,PP-354-359,Y-2018

15. Shendge R.B., Chockalingam M.P.,A review on soil and water assessment tool,International Journal of Mechanical Engineering and Technology,V-9,I-2,PP-347-353,Y-2018

16. Sachithanandam P., Meikandaan T.P., Srividya T.,Steel framed multi storey residential building analysis and design,International Journal of Applied Engineering Research,V-9,I-22,PP-5527-5529,Y-2014

17. Meikandaan T.P., Ramachandra Murthy A.,Study of damaged RC beams repaired by bonding of CFRP laminates,International Journal of Civil Engineering and Technology,V-8,I-2,PP-470-486,Y-2017

18. Meikandaan T.P., Ramachandra Murthy A.,Retrofittng of reinforced concrete beams using GFRP overlays,International Journal of Civil Engineering and Technology,V-8,I-2,PP-423-439,Y-2017

19. Meikandaan T.P., Ramachandra Murthy A.,Flexural behaviour of RC beam wrapped with GFRP sheets,International Journal of Civil Engineering and Technology,V-8,I-2,PP-452-469,Y-2017

20. Meikandaan T.P., Murthy A.R.,Experimental study on strengthening of rc beams using glass Fiber,International Journal of Civil Engineering and Technology,V-9,I-11,PP-959-965,Y-2018

21. Meikandaan T.P., Hemapriya M.,Use of glass FRP sheets as external flexural reinforcement in RCC Beam,International Journal of Civil Engineering and Technology,V-8,I-8,PP-1485-1501,Y-2017

22. Saraswathy R., Saritha B.,Planning of integrated satellite township at Thirumazhisai,International Journal of Applied Engineering Research,V-9,I-22,PP-5558-5560,Y-2014

23. Saritha B., Ilayaraja K., Eqyaabal Z.,Geo textiles and geo synthetics for soil reinforcement,International Journal of Applied Engineering Research,V-9,I-22,PP-5533-5536,Y-2014

24. Ambica A., Saritha B., Changring G., Singh N B., Rajen M., Salman Md.,Analysis of groundwater quality in and around Tambaram taluk, Kancheepuram district,International Journal of Civil Engineering and Technology,V-8,I-8,PP-1362-1369,Y-2017

25. Arunya A., Sarayu K., Ramachandra Murthy A., Iyer N.R.,Enhancement of durability properties of bioconcrete incorporated with nano silica,International Journal of Civil Engineering and Technology,V-8,I-8,PP-1388-1394,Y-2017

26. Ilayaraja K., Krishnamurthy R.R., Jayaprakash M., Velmurugan P.M., Muthuraj S.,Characterization of the 26 December 2004 tsunami deposits in Andaman Islands (Bay of Bengal, India),Environmental Earth Sciences, V-66,I-8,PP-2459-2476,Y-2012

27. Ilayaraja K.,Morphometric parameters of micro watershed in Paravanar sub-basin, Cuddalore District,International Journal of Civil Engineering and Technology,V-8,I-8,PP-1444-1449,Y-2017

28. Ilayaraja K., Singh R.K., Rana N., Chauhan R., Sutradhar N.,Site suitability assessment for residential areas in south Chennai region using remote sensing and GIS techniques,International Journal of Civil Engineering and Technology,V-8,I-8,PP-1468-1475,Y-2017

29. Ilayaraja K., Reza W., Kumar V., Paul S., Chowdhary R.,Estimation of land surface temperature of Chennai metropolitan area using Landsat images,International Journal of Civil Engineering and Technology,V-8,I-8,PP-1450-1456,Y-2017

30. Chitra R.,Experimental study on beam using steel fiber and latex,International Journal of Civil Engineering 


\section{Audit on Factors Causing Cost Over Runs in Construction Industry}

Technology,V-8,I-8,PP-1395-1403,Y-2017

31. Chitra R.,Analysis of traffic and management at Kovilambakkam intersection,International Journal of Civil Engineering and Technology,V-8,I-8,PP-1433-1443,Y-2017

32. Aswathy M.,Experimental study on light weight foamed concrete,International Journal of Civil Engineering and Technology,V-8,I-8,PP-1404-1412,Y-2017

33. Aswathy M.,Wastewater treatment using constructed wetland with water lettuce (Eichornia Crasipies),International Journal of Civil Engineering and Technology,V-8,I-8,PP-1413-1421,Y-2017

Kiruthiga K., Anandh K.S., Gunasekaran K, Assessment of influencing factors on improving effectiveness and productivity of construction engineers, 2015, International Journal of Applied Engineering Research, V - 10,I -17,p -13849-13854

\section{AUTHORS PROFILE}

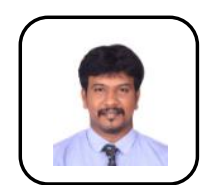

S. Venkat Raman Assistant Professor, Department of Civil Engineering, Bharath Institute of Higher Education and Research, Chennai , India.

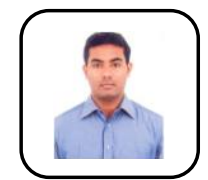

Anish.C, Assistant Professor Department of Civil Engineering, Bharath Institute of Higher Education and Research, Chennai , India.

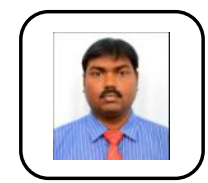

S.Rajesh, Assistant Professor Department of Civil Engineering, Bharath Institute of Higher Education and Research, Chennai , India.

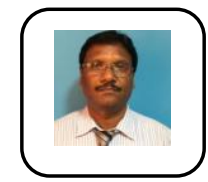

R.Venkatakrishnaiah, Associate Professor Department of Civil Engineering, Bharath Institute of Higher Education and Research, Chennai, India. 